\title{
Hanna Solarczyk-Szwec, Agata Szwech (red.), Inspiracje pedagogiq freinetowskq, tom 2: Dzienniki Haliny Semenowicz - matki i obywatelki, Wydawnictwo Naukowe Uniwersytetu Mikołaja Kopernika, Toruń 2016, ss. 376
}

Przed przystąpieniem do omawiania drugiego tomu Inspiracji pedagogia freinetowskq trudno nie nawiązać do wydanego w 2014 roku tomu pierwszego (współredagowanego także przez Aleksandrę Semenowicz), dedykowanego Halinie Semenowicz, pionierce w propagowaniu pedagogii Celestyna Freineta i twórczyni ruchu freinetowskiego w Polsce. Tom ten zawiera opracowania autorów pochodzących ze środowiska naukowego oraz z grona nauczycieli freinetowskich. Teksty w nim zamieszczone dotyczą wielostronnej analizy i interpretacji freinetowskiej pedagogii, dziejów ruchu freinetowskiego w Polsce w kontekście biografii i zasług Haliny Semenowicz oraz dyskusji na temat współczesnej edukacji i szkoły. Należy zwrócić uwagę na to, że w tomie tym ukazane zostało teoretyczno-metodologiczne tło empirycznej pracy nad Dziennikami Haliny Semenowicz, której pełny rezultat otrzymuje czytelnik w tomie drugim. Kolejny tom można jednak traktować jako dzieło autonomiczne, będące rozwiązaniem ciągle rzadko spotykanym w polskim środowisku pedagogicznym. Mamy bowiem do czynienia z poważnym opracowaniem naukowym będącym efektem pracy studentów i nauczycieli akademickich. Studentów wymieniam przed nauczycielami nie bez powodu, do czego jeszcze powrócę. Popatrzmy najpierw na aspekty naukowe opracowania.

Naukowe walory recenzowanej książki, jej wysoki poziom merytoryczny uwypukla doskonale przemyślana struktura. Znaczącym pomysłem wpływającym na poziom naukowy całego recenzowanego tomu jest przedstawiona w części I rama teoretyczno-metodologiczna w postaci metody biograficznej, badań biograficznych, a przede wszystkim biograficznego uczenia się. Mamy tu też prezentację metodologicznych aspektów badań przedstawionych w drugiej części i podsumowanych w części trzeciej.

Wysoki naukowy ton nadaje recenzowanej pracy tekst Hanny Solarczyk-Szwec Cztery ćwiartki biograficznego uczenia się zawierający pogłębioną 
analizę czterech „wymiarów” biograficznego uczenia się: jednostkowego (ucząca się jednostka), społecznego (uczące się społeczności), świadomości i nieświadomości biograficznego uczenia się. Rozważania prowadzone są tu w szerokim kontekście teoretycznym z odwoływaniem się do bogatej i reprezentatywnej literatury przedmiotu. Swoboda narracji i integralność wywodów czyni to opracowanie przyjaznym dla czytelników o różnym zaawansowaniu w problematyce metodologicznej.

Tekst Hanny Solarczyk-Szwec i Agaty Szwech Metodologia badania dzienników Haliny Semenowicz opisujący zastosowane procedury badawcze doskonale przygotowuje do percepcji części drugiej książki, czyli do analizy dzienników. I tu dochodzimy do kolejnego atutu naukowego recenzowanej pozycji, w bardziej wąskim wymiarze, a mianowicie do ukazania dzienników jako źródła wiedzy i biograficznego uczenia się.

Polecając drugi tom dzieła Inspiracje pedagogia freinetowskq m.in. nauczycielom akademickim, należy wskazać na jego walor dydaktyczny, wręcz praktyczny $\mathrm{w}$ postaci prezentacji interesującego i godnego naśladowania pomysłu na zajęcia projektowe ze studentami oraz na seminarium magisterskie wprowadzające studentów pedagogiki w arkana wiedzy metodologicznej i dające szanse na autentyczne zaangażowanie w pracę naukową. Metodologia bowiem nie jest tu teoretycznym konstruktem do opanowania i odtworzenia na egzaminie. Dodam, że teksty w części drugiej (J. Chojnackiej, E. Piwowarskiej, B. Walewicz, M. Rutkowskiej), będące rezultatem pracy w ramach seminarium magisterskiego wyróżniają się skrupulatnością analiz, interesującymi interpretacjami, a ich autorki w sposób wyrazisty wykazują się świadomością metodologiczną. Spośród tekstów powstałych w ramach zajęć projektowych warto zwrócić uwagę m.in. na opracowania: M. Jedlińskiej, A. M. Wiśniewskiej, czy też na tekst czterech autorek pt. Ilościowa i jakościowa analiza dziennika Haliny Semenowicz z 1997 roku. Pokazują one pozytywne efekty prowadzonego na tych zajęciach (projektowych) kształcenia metodologicznego, w zakresie metody biograficznej, pozwalającego na realizację badań według procedury metodologicznej przedstawionej w tekście Solarczyk-Szwec i Szwech (cześć I).

Akcentując zaangażowanie studentów w znaczące działania naukowe, stawianie ich w roli badaczy i twórców tekstów naukowych, należy stwierdzić, że mamy tu do czynienia z klasycznym wykorzystaniem freinetowskiej techniki doświadczeń poszukujących na poziomie akademickim i to z niezwykle znaczącym rezultatem. Dobrze więc, że na ten istotny fakt zwraca się uwagę czytelnika już we Wprowadzeniu, zwłaszcza że w drugiej części książki do pedagogii Celestyna Freineta autorzy tekstów nawiązują wielokrotnie. 
W opracowaniu zbiorowym przy zaangażowaniu dużego zespołu studentów mogą pojawić się teksty mniej interesujące zarówno na poziomie analiz, jak i w aspekcie metodologicznym. Wydaje się, że tak właśnie jest w przypadku opracowań Anny Kołtek i Eweliny Osińskiej oraz Michała Jaśkiewicza i Zofii Zagraby. Są one jednak dobrze wpasowane w strukturę drugiej części książki i merytorycznie stanowią ważną część dzieła.

Warto także zwrócić uwagę na trzecią cześć książki stanowiącą „Posłowie". Zamieszczone tam teksty Agaty Szwech i Aleksandry Semenowicz stanowią interesujące podsumowanie obu poprzednich części, zarówno stanowiącej ramę teoretyczno-metodologiczną, jak i tej, która zawiera analizy dzienników Haliny Semenowicz.

Opracowanie Szwech prezentuje materiał badawczy w postaci refleksji studentów - uczestników projektu - po lekturze i analizie dzienników. Zgromadzony przez autorkę materiał empiryczny pokazuje stosunek młodych badaczy (studentów) „do biografii Innego” oraz edukacyjne oddziaływanie biografii Haliny Semenowicz na odbiorców (s. 360). Owe wypowiedzi badanych studentów dotyczyły m.in. cech dziennika, podejmowanych w nim tematów i opisywanych relacji interpersonalnych oraz odczuć mówiących o tym, czego nauczyli się „z biografii Innego”.

Wypowiedź Aleksandry Semenowicz, Dzienniki Haliny Semenowicz w życiu córek, pokazuje, że źródłem biograficznego uczenia się mogą być materiały pamiętnikarskie stworzone przez własną matkę. Autorka wskazuje np., że lektura Dzienników pozwalała jej i siostrze rozumieć sytuację społeczno-polityczną i przemiany ustrojowe w Polsce. A dziś „umożliwiają one młodym czytelnikom, przyszłym nauczycielom poznanie świata, w którym żyła Halina Semenowicz. Dla córki Aleksandry są źródłem otuchy i podpowiadają, jak zachować właściwe proporcje między tym, co w życiu ważne, a co błahe" (s. 376).

Wspomniałem już, że recenzowaną tu książką powinni zainteresować się nauczyciele akademiccy, dla których ważna jest troska o naukowy poziom kształcenia w uniwersytecie. Ale przede wszystkim może ona być ważnym źródłem wiedzy i inspiracji dla badaczy chcących posługiwać się metodą biograficzną oraz dla pedagogów (nie tylko andragogów), dla których interesująca kategorią jest biograficzne uczenie się. $Z$ dużą satysfakcją przyjmą ją zapewne czytelnicy zainteresowani pedagogią Celestyna Freineta, ruchem freinetowskim w Polsce oraz dokonaniami inspiratorki tego ruchu i propagatorki freinetowskiej idei pedagogicznej - $d r$ Haliny Semenowicz. 